\title{
Reference Result Reference Type Code
}

National Cancer Institute

\section{Source}

National Cancer Institute. Reference Result Reference Type Code. NCI Thesaurus. Code C95388.

A coded value specifying the reference type of the reference result. 